\title{
Water retainer polymer in coffee plants deployment under different levels of irrigation
}

\author{
Thales Barcelos Resende ${ }^{1}$, Victor Hugo Silva Souza ${ }^{2^{*}}\left(\mathbb{D}\right.$, Dalyse Toledo Castanheira ${ }^{2} \mathbb{D}$, \\ Milene Alves de Figueiredo Carvalho ${ }^{3} \mathbb{D}$, Rubens José Guimarães ${ }^{2} \mathbb{E}$
}

\author{
${ }^{1}$ Omex Agrifluids do Brasil, Piumhi, MG, Brasil \\ ${ }^{2}$ Universidade Federal de Lavras/UFLA, Departamento de Agricultura/DAG, Lavras, MG, Brasil \\ ${ }^{3}$ Empresa Brasileira de Pesquisa Agropecuária/Embrapa Café, Brasília, DF, Brasil \\ Contact authors: thalesr@omex.com; victorhssouza@hotmail.com; dalyse.castanheira@ufla.br; milene.carvalho@embrapa.br; rubensjg@ufla.br \\ Received in May 20, 2021 and approved in November 5, 2021
}

\section{ABSTRACT}

The use of water-retaining polymers may be a feasible alternative in regions with low water availability, as they has enhance the performance of coffee plants with more favorable anatomical characteristics to make physiological processes more efficient. However, the advantages of such use have been scarcely reported. Here, we studied the feasibility of using a water-retaining polymer to optimize irrigation water use during the establishment of a coffee plantation. A randomized block design was used in a factorial scheme $(4 \times 2)$ with three replications for a total of 24 experimental plots, each consisting of four pots, with one plant per unit. The experiment was installed in a greenhouse at the Coffee Science Department of the Universidade Federal de Lavras, Minas Gerais, Brazil, with four levels of irrigation $(25 \%, 50 \%, 75 \%$, and $100 \%$ of soil water at field capacity), with or without addition of the water-retaining polymer. Growth variables evaluated included: plant height, stem diameter, number of leaves, shoot and root dry weights, root volume and area. Additionally, gas exchange, leaf water potential, and leaf anatomy were analyzed. The use of water-retaining polymer during establishment of the coffee plantation ensured sufficient water supply, thus guaranteeing plant anatomical and physiological functionality and, consequently, a healthy, vigorous growth.

Key words: Coffea arabica L.; Seedling establishment; Soil conditioner; Soil water availability; Water deficit.

\section{INTRODUCTION}

Many factors are involved and interact in the coffee production system in a sequence of events including stand establishment, phytosanitary control, harvest, and post-harvest. Among these, stand establishment must be highlighted, as coffee is a perennial crop whose success at this stage depends largely on proper choice of the plantation site, land preparation, and the planting itself (Guimarães, et al., 2019).

Further, a rational use of irrigation water in crops allows greater growth and yields (Faria; Siqueira, 2005); however, water is a scarce resource in most coffee regions, particularly, in those where rainfall is normally concentrated during certain periods of the year, while low water availability prevails at other times, consequently limiting plant growth and crop productivity.

Therefore, the use of water-retaining polymers that are capable of retaining rain or irrigation water for plants to use in periods of water deficit, thus optimizing water availability and reducing percolation losses while improving soil aeration and drainage, may provide a viable alternative in such regions (Lamont; O’Connell, 1987).

The use of water-retaining polymers reportedly enhanced the performance of plants showing more favorable anatomical characteristics to make physiological processes more efficient regardless of water availability (Castanheira et al., 2019). Consistently, Souza et al. (2016), observed greater plant growth upon soil treatment with water-retaining polymers than in their absence.

Studies focusing on the use of water-retaining polymers in coffee plantations are scarce at best. Therefore, this study aimed to evaluate the effect of water-retaining polymers at different levels of irrigation on plant performance during the establishment of coffee plantations, as a means to optimize water use.

\section{MATERIAL AND METHODS}

The experiment was conducted in a greenhouse at the Coffee Science Department of the Universidade Federal de Lavras, between June and October 2015, using coffee (Coffea arabica L.) seedlings of cv. 'Aranãs' as plant material.

Water replenishment level and water-retaining polymer were tested in a factorial scheme with four levels of soil water replenishment; namely, $25 \%, 50 \%, 75 \%$, or $100 \%$ of field capacity, and two polymer conditions, i.e., with or without addition of the water-retaining polymer, with three replications, for a total of 24 experimental plots, each consisting of four pots with one plant per pot. In all, 96 polyethylene pots $(11 \mathrm{~L})$ were prepared by filling with a medium texture, typical, dystrophic oxisol, sandy textured soil, whose characteristics chemical are: $\mathrm{pH} \mathrm{CaCl}=4.9$, contents of $\mathrm{Al}^{3+}, \mathrm{Ca}^{2+}, \mathrm{Mg}^{2+}, \mathrm{K}^{+}, \mathrm{SB}, \mathrm{CTC}=$ $0.00 ; 2.4 ; 0.7 ; 0.28 ; 3.39$ and $7.59 \mathrm{cmol} \mathrm{dm}^{-3}$, respectively and $\mathrm{V} \%=44.66$ and $\mathrm{m}=0.00 \% \mathrm{P}$ and $\mathrm{S}=4.20$ and $10.10 \mathrm{mg} \mathrm{dm}^{-3}$ 
respectively. Collected in a pasture area at a depth of 0-20 cm to maintain conditions similar to those in the field.

Soil amendment was performed by raising the base saturation to $60 \%$ (Guimarães et al., 1999) with a mixture of limestone and humid soil made into a heap and covered with plastic canvas for 16 days. The pots thus prepared were placed on benches $0.8 \mathrm{~m}$ from the ground at a spacing of $0.70 \times 0.60 \mathrm{~cm}$.

Coffee seedlings were transplanted to the pots, with or without addition of the polymer, and kept in the greenhouse under identical irrigation for 60 days until establishment (setting) was verified. The water-retaining polymer was applied at a rate of $1.5 \mathrm{~L} /$ pot after hydration (the solution consisted of $1.5 \mathrm{~kg}$ of polymer diluted in $400 \mathrm{~L}$ of water) at the time of planting, as recommended by Pieve et al. (2013).

Prior to water treatment initiation, pots were immersed in a water tank up to half their height, such that capillary raise would gradually fill the soil pores. Then, pots were removed from the tank and allowed to drain freely for $24 \mathrm{~h}$ before measuring their weight at $100 \%$ field capacity to ensure equal initial soil-humidity conditions in all pots. Throughout the experimental period, the amount of irrigation water to apply was calculated by taking into account the evaporation from a "Class A Pan", measured by a micrometric screw. Installation, readings, and management of the "class A evaporation pan" was carried out as recommended by Bernardo (1987). The pan (50 $\mathrm{cm}$ in diameter and $39 \mathrm{~cm}$ high), was installed inside the greenhouse on a $0.8 \times 0.8 \mathrm{~m}$ support leveled with the ground.

Water replenishment in the evaporation pan was performed once a week, measuring the readings in the screw before and after completing the volume of the pan, thus making it easier to calculate evapotranspiration. The "class A pan" was filled with water up to $5 \mathrm{~cm}$ below the upper edge, and then a still pipe was placed inside the pan in order to reduce water movement. After completing all readings, the amount of water to be applied to each pot was calculated using a simple "Microsoft Excel" spreadsheet that contained the evaporation values measured by the micrometric screw, the coefficient (Kp $=0.8$ ) for a class A pan, and the pot area.

Plant measurements were performed 105 days after water treatment differentiation. Destructive growth evaluations were carried out at the end of the experiment, i.e., 165 days after seedling transplantation. Stem diameter $(\mathrm{mm})$ was measured using a digital caliper immediately below the insertion of the cotyledon leaf; plant height was measured with a graduated ruler (centimeters) from the collar to the apical meristem, and the number of leaves was determined by counting true leaves ( $>2.5 \mathrm{~cm}$ ) after Gomide et al. (1977).

At the end of the experiment, after growth evaluation, plants were sectioned in the neck region to separate the shoots (leaves and stems) from the roots. The roots were washed under running water, placed on a white surface long enough to frame the roots completely, and then photographed $($ a $5 \mathrm{~cm}$ scale was placed on the side for future measurements). The analysis of these photographs, 96 altogether, was performed independently for each plant; then, after obtaining the images, these were processed and analyzed using SAFIRA, Sistema de Análise de Fibras e Raízes (fiber and root analysis system), a software developed by Embrapa Instrumentação (Jorge; Silva, 2010). Subsequently, the plant material harvested from each plot (four plants) was placed in paper bags and oven-dried under forced-air at $65{ }^{\circ} \mathrm{C}$ to a constant weight. Each sample was weighed on a precision scale to determine leaf dry mass (LDM), root dry mass (RDM), and stem dry mass (SDM).

Predawn (03:00 to 05:00 hours) leaf water potential (MPa) was measured with a Scholander pressure pump (Model 1000, PMS Instrument Company, Albany, OR, USA). Photosynthetic rate $\left(\mu \mathrm{mol} \mathrm{CO} \mathrm{m}^{-2} \mathrm{~s}^{-1}\right)$, stomatal conductance $\left(\mathrm{mol} \mathrm{H} \mathrm{O} \mathrm{m}^{-2} \mathrm{~s}^{-1}\right)$, and transpiration rate $\left(\mathrm{mmol} \mathrm{m} \mathrm{m}^{-2} \mathrm{~s}^{-1}\right)$ were measured between 08:00 to 10:00 hours using an infrared gas analysis system (IRGA LI-COR 6400XT, Lincoln, NE, USA) under artificial light $\left(1000 \mu \mathrm{mol} \mathrm{m} \mathrm{m}^{-2} \mathrm{~s}^{-1}\right)$.

A total of 24 fully expanded leaves (one from each experimental plot) were collected at the end of the experiment for anatomical studies. The leaves were fixed in $70 \%$ ethanol $\left(\mathrm{v} \mathrm{v}^{-1}\right)$ for approximately $72 \mathrm{~h}$ and, then, after changing solution, they were preserved in the same reagent $70 \%$ ethanol $\left(\mathrm{v} \mathrm{v}^{-1}\right)$. Cross sections were obtained using a microtome table (LPC type) and para-dermic sections were prepared manually using a steel blade. These cross sections were subjected to clarification with sodium hypochlorite $(1.25 \%$ active chlorine), triple washing in distilled water, and staining with astra blue stain solution $(0.1 \%$ astra blue and $1 \%$ safranin at a ratio of $7: 3$ ). The para-dermic sections were stained with $1 \%$ safranin and then set on semi-permanent slides with $50 \%$ glycerol ( $\left.\mathrm{v} \mathrm{v}^{-1}\right)$ (Kraus; Arduin, 1997). Slides were observed and photographed using a BX 60 Olympus optical microscope coupled to a Canon A630 digital camera. For each statistical replication of the treatments, nine photographs were taken using two slides with cross sections (three images of the blade and three of the middle vein) and three others for the para-dermal sections, always from different cross sections. The images obtained were analyzed using the specific software for image analysis, UTHSCSA-Imagetool. The characteristics evaluated in the cross sections included, adaxial cuticle thickness (ACT), palisade parenchyma thickness (PPT), spongy parenchyma thickness (SPT), mesophyll thickness (MT), xylem vessel diameter XVD, and phloem thickness (PHT). The number of xylem vessels (XVs) was also determined.

Stomatal density (SD, number of stomata per $\mathrm{mm}^{2}$ ) and the ratio between polar and equatorial diameters were evaluated by observation of para-dermal sections. Collected data were tabulated and tested for normality and homogeneity, and then subjected to analysis of variance (ANOVA). Significant interactions were studied through regression analysis after 
Banzatto and Kronka (1995). Finally, the Scott Knott test ( $p$ $<0.05$ ) was used for comparison of means of qualitative data and regression models that best fit the quantitative variables. All results were analyzed by the statistical analysis software, SISVAR $®$ (Ferreira, 2011).

\section{RESULTS}

The water-retaining polymer had a positive effect on coffee plant growth (height, stem diameter, and root dry mass) regardless of irrigation level. On average, polymer-treated plants increased $5.75 \mathrm{~cm}$ in height, $1.46 \mathrm{~mm}$ in stem diameter, and $2.59 \mathrm{~g}$ in root dry mass, compared to plants that were not treated by application of the polymer (Table 1).
We observed that plants that did not receive the waterretaining polymer showed a higher mean ratio of polar to equatorial stomatal diameter than polymer-treated plants (Table 1).

An increasing linear trend was also observed in the number of leaves, leaf dry matter weight, and root volume, as soil water availability increased up to $100 \%$ of the field capacity level of soil humidity level (Figures 1A, 1C, and 1D). Thus, a quadratic effect was observed for stem diameter (Figure 1B), which peaked at $6.67 \mathrm{~mm}$, when water was at $79.30 \%$ of field capacity. Irrigation allowed greater growth of both plant shoot and root, up to $100 \%$ of soil water available at field capacity (Figures 1A, 1C, and 1D), indicating, as desirable, a balanced growth between the shoot and root systems.

Table 1: Mean height $(\mathrm{H})$, stem diameter (SD), root dry mass (RDM) and stomatal functionality (SF) of coffee plants in the presence or absence of a water-retaining polymer applied at seedling transplanting, regardless of irrigation level.

\begin{tabular}{lllll}
\hline \multicolumn{1}{c}{ Water-retaining Polymer } & $\mathrm{H}(\mathrm{cm})$ & $\mathrm{SD}(\mathrm{mm})$ & $\mathrm{RDM}(\mathrm{g})$ & $\mathrm{SF}$ \\
\hline Presence & $36.08 \mathrm{a}$ & $6.77 \mathrm{a}$ & $7.54 \mathrm{a}$ & $1.46 \mathrm{~b}$ \\
Absence & $30.33 \mathrm{~b}$ & $5.31 \mathrm{~b}$ & $4.95 \mathrm{~b}$ & $1.52 \mathrm{a}$
\end{tabular}

Means within columns followed by the same lowercase letter do not differ significantly, as per the Scott-Knott test at the $5 \%$ probability level.
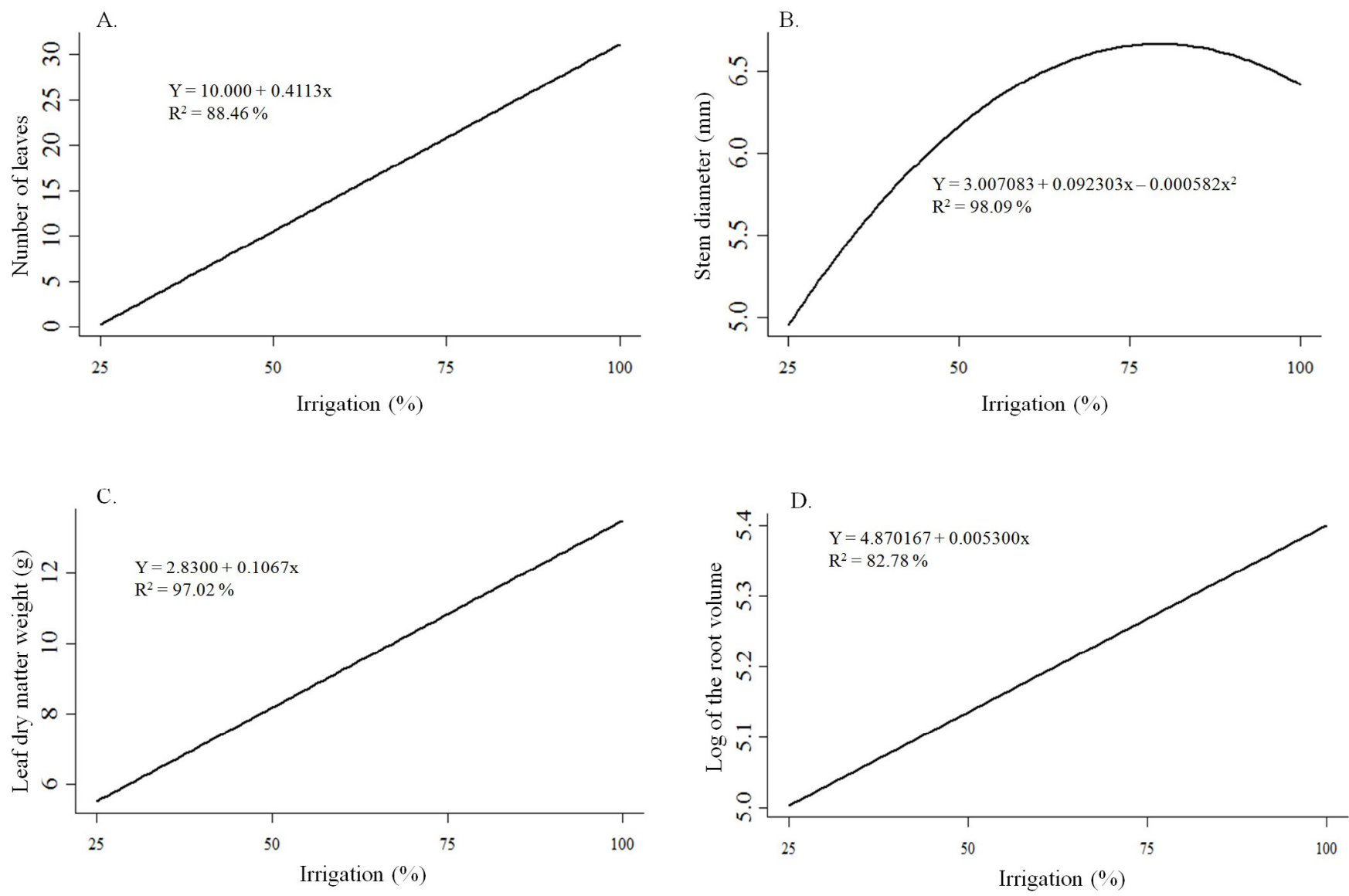

Figure 1: Mean number of leaves (A), stem diameter (B), Leaf dry matter weight (C) and log of root volume (D) of coffee plants as a function of irrigation level. 
The thickness of palisade parenchyma varied in plants with or without polymer application, depending on soil water availability (Figure 2A). Thus, the thickness of palisade parenchyma in polymer-treated plants behaved in a quadratic manner, increasing to a maximum at $48 \%$ of soil water availability, and decreasing with increasing irrigation level. When the water-retaining polymer was not used, palisade parenchyma reached a greater thickness at $65 \%$ of soil humidity at field capacity. In other words, it was necessary to increase the volume of irrigation water by $17 \%$ for polymer-untreated plants to reach greater palisade-parenchyma thickness.

A linear decrease was observed in mesophyll thickness with increasing plant water availability in polymer-treated plants. In contrast, a quadratic behavior was observed for polymer-untreated plants. Furthermore, mesophyll thickness was consistently greater in polymer-treated plants. In other words, the presence of the water-retaining polymer ensured a greater thickness of palisade parenchyma and mesophyll with a smaller amount of irrigation water, when compared to treatments which did not include polymer application (Figure 2A and 2B).

As shown in Figure 2C, 2D, a decreasing quadratic behavior was observed for xylem vessel diameter and phloem thickness with increasing water availability, only for treatments involving the water-retaining polymer.
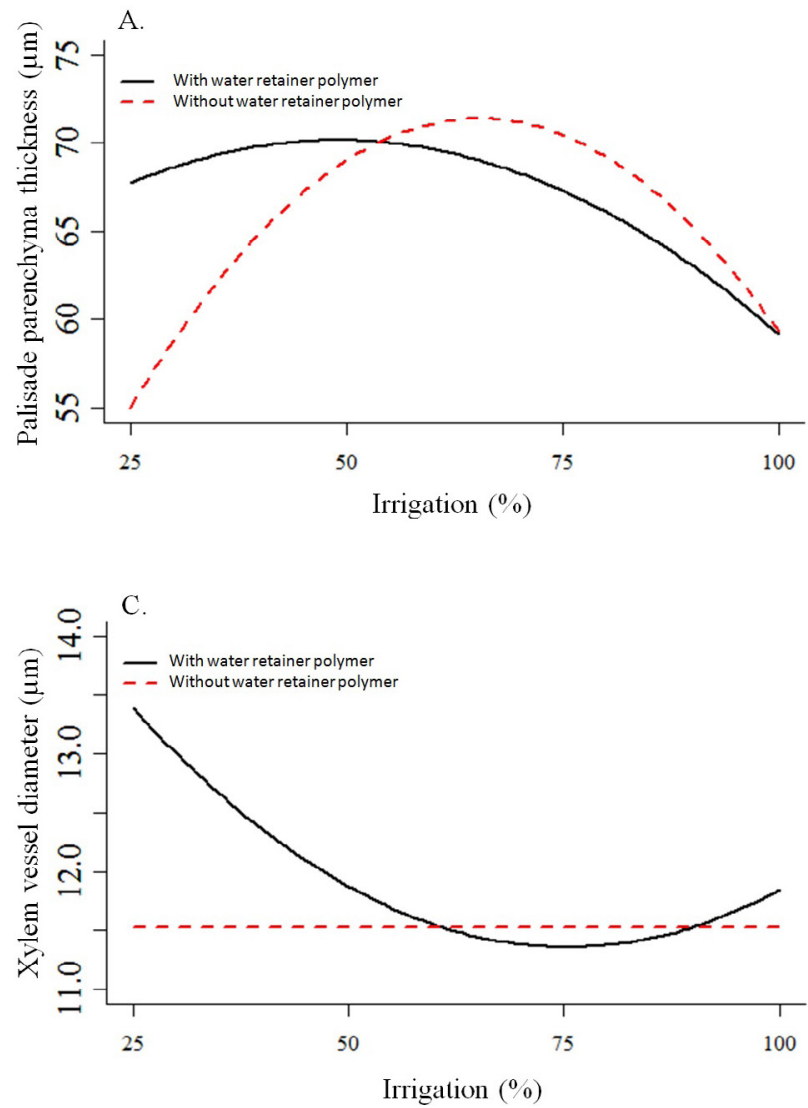

Figure $3 \mathrm{~A}-3 \mathrm{C}$ shows a quadratic behavior for the square root of stomatal conductance, the square root of transpiration, and photosynthesis, obtaining a maximum efficiency point in the range of $65 \%-70 \%$ of field capacity, with maximum values at $0.1286,0.6242$, and $5.1173 \mu \mathrm{mol} \mathrm{CO} \mathrm{m}^{-2} \mathrm{~s}^{-1}$, respectively.

Leaf water potential showed a quadratic response to irrigation level, peaking at a maximum value of $-0.04 \mathrm{MPa}$, at $80 \%$ of field capacity (Figure 4 ). The lowest value for leaf water potential (i.e., most negative value) observed in this study was $-0.52 \mathrm{MPa}$ at $25 \%$ of field capacity.

\section{DISCUSSION}

In regions that have low availability of water for irrigation, or even in a region that has satisfactory levels of precipitation, water deficits have been observed due to climate change. The positive effect of using the water-retaining polymer is in the greater water retention capacity in the soil and, consequently, in the greater availability of water for the plant (Prevedello; Balena, 2000). Besides, the addition of polymer to the soil reduces losses due to water percolation and leaching of nutrients, ensuring better aeration and drainage of the soil, favoring the development of the root system (Azevedo et al., 2002).
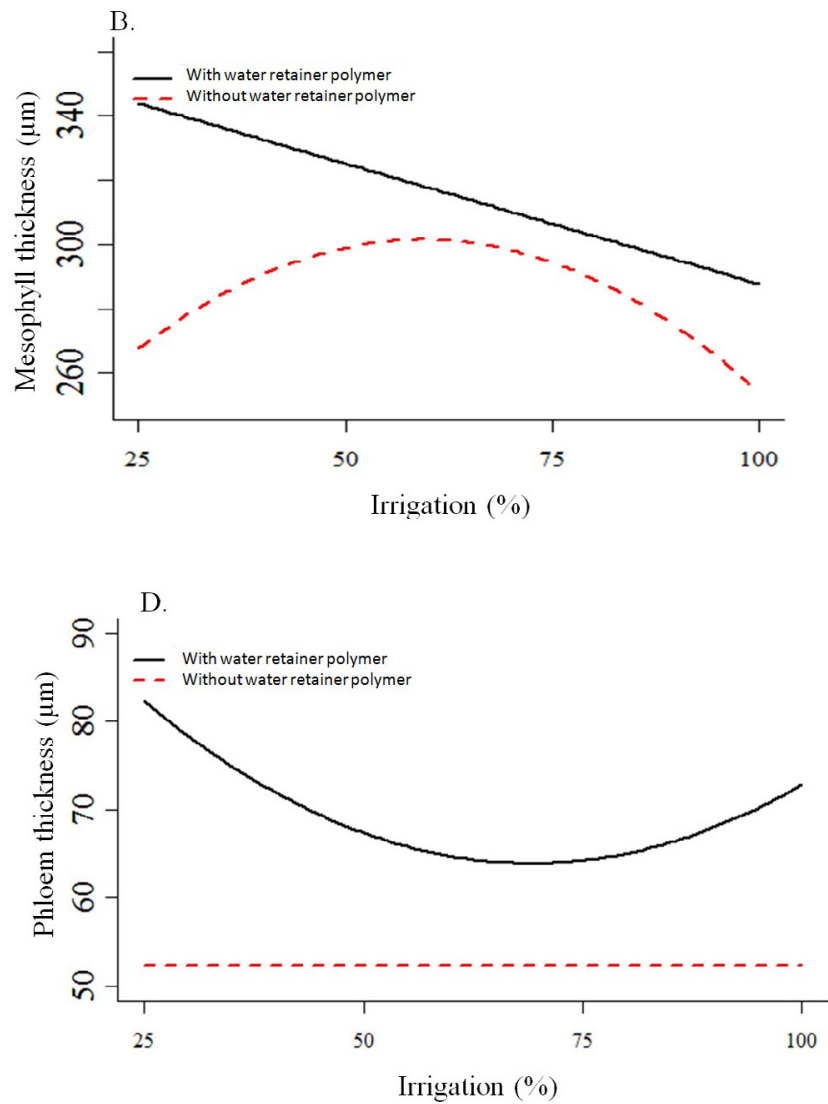

Figure 2: Palisade parenchyma thickness $(A)$, mesophyll thickness $(B)$, xylem vessel diameter (C) and phloem thickness (D) in function of the use or not of water retaining polymer and irrigation levels for coffee plants in the early stage of growth. 

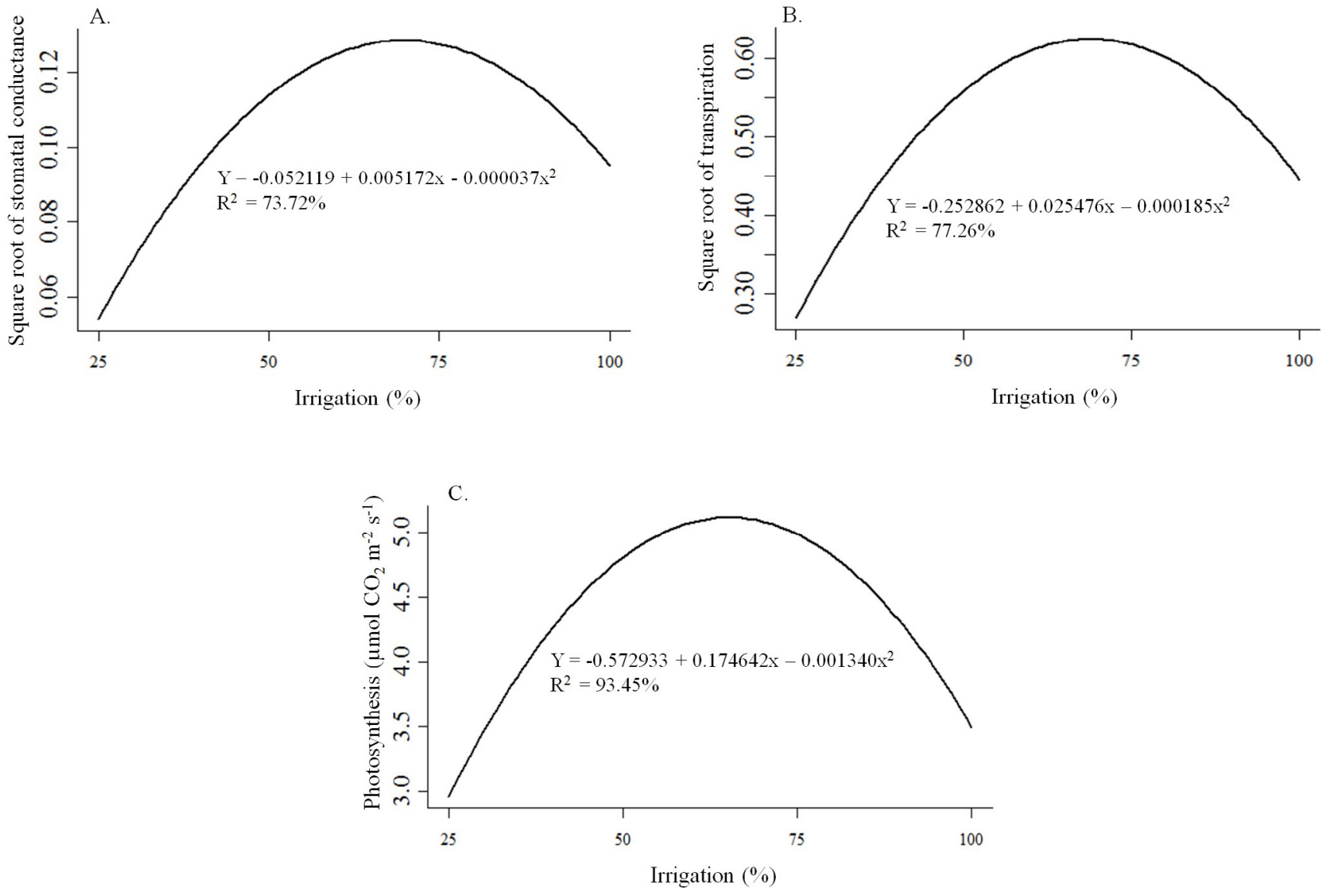

Figure 3: Square root of stomatal conductance (A), square root of transpiration (B) and photosynthesis (C) young coffee seedlings, as a function of irrigation level.

For the production of seedlings in nurseries, the use of the polymer can reduce water consumption by allowing an increase in the interval between irrigations, without interfering in the development of plants (Azevedo et al., 2002).

In general, in the present work, gains were observed in the vegetative growth of the plants treated with the water-retaining polymer. These findings were in agreement with those reported by Pieve et al. (2013), Azevedo et al. (2002), and Marques et al. (2013), who observed positive results of the use of waterretaining polymers in coffee plants or seedlings. However, in other study (Vallone et al., 2004) it was not possible to observe the positive changes found in the present study. In the present article, the reduction in stem diameter below $79.30 \%$ of the field capacity can be explained by partial stiolation due to the greater growth in height of the plagiotropic branch. However, this reduction will not affect the balance in plant growth.

The work of Pieve et al. (2013) was important for research on water-retaining polymers in coffee production, not only because it pointed the positive effects on early plant growth, as in the study reported herein but, additionally, because it made it possible to recommend the use of $1.5 \mathrm{~L}$ of the polymer solution $(5 \mathrm{~kg}$ of dry product hydrated in $400 \mathrm{~L}$ of water) mixed with the soil in each pot, for application at the time of seedling transplanting to the field.

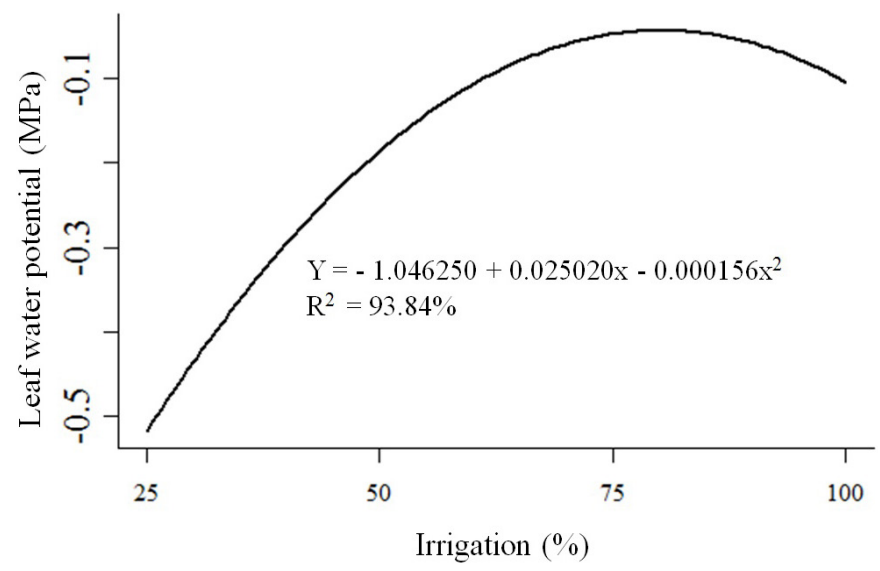

Figure 4: Leaf water potential (MPa) of coffee plants in the early growth stage in response to irrigation level.

In our series, a higher mean ratio between the polar and the equatorial diameter, observed in plants not treated with polymer (Table 1), explains the extent of the forced adaptation of the leaf anatomy in order to support a greater water deficit. This higher proportion indicates an ellipsoid shape of the stomata (Batista et al., 2010; Grisi et al., 2008), which favors gas exchange, as it allows greater absorption of 
carbon dioxide with less stomatal opening, thus reducing loss of transpirational water (Souza et al., 2010).

Variations in stomatal behavior, in relation to their size, is a very characteristic variable in plants depending on the environment (Melo et al., 2004), genetics of species constitution (Camargo; Marenco, 2011) and frequently in plants subjected to different stresses (Castro et al., 2005).

In the specialized literature, we already found in 2011 reports by Kufa and Burkhardt (2011) describing stomata anatomy and distribution characteristics in arabic coffee, and it was clear that the stomatal area index was significantly higher in leaves exposed to the sun than in shaded leaves, there was no difference in stomatal densities did not differ between coffee accessions (the lowest and highest values were determined for Harenna and Yayu coffees, respectively).

Harrison et al. (2020) explored how thecontributions of stomatal morphology and distribution can affect photosynthesis, through changes in gas-eous exchange. The factors driving this relationship are considered, and recent results from studies investigating the effects of stomatal shape, size, density and patterning on photosynthesis are discussed. Suggested that the interplay between stomatal gaseous exchange and photosynthesis is complex, and that a disconnect often exists between the rates of $\mathrm{CO}_{2}$ diffusion and photosynthetic carbon fixation. The mechanisms that allow for substantial reductions in maximum stomatal conductance without affecting photosynthesis are highly dependent on environmental factors and could be exploited to improve crop performance.

The correct use of irrigation or other technologies to optimize water use (such as the use of water-retaining polymers) increases coffee plant growth while minimizing or even eliminating harmful effects of water deficit (Assis et al., 2014; Carvalho et al., 2006; Castanheira et al., 2019).

Oliveira et al. (2014) found that the use of the waterretaining polymer technology favored both an increase in palisade parenchyma thickness and greater chloroplast abundance, thereby contributing to the photosynthetic process.

Mesophyll thickness is the sum of the thickness of palisade and spongy parenchyma in the leaf. Therefore, in the present study, a greater thickness of mesophyll correlated with a greater thickness of palisade parenchyma in polymertreated plants. Nagy-Déri et al. (2011) suggested that palisade parenchyma cells are more responsive to water availability than spongy cells, as observed in this study.

Conductive vessels are vital for proper plant metabolism, as they transport water and nutrients to the different parts of the plant, allowing their growth (Morandi et al., 2014). Thus, any modification in xylem and phloem vessels, such as in their constitution (Liu; Chang; Chiou, 2013), functioning (Sevanto, 2014), or diameter and number (Hölttä et al., 2009), among others, may occur due to the actual plant water availability experienced by the plant. In this study, the presence of the water-retaining polymer at the time of seedling transplanting enabled an increase in the diameter of the xylem vessels and in the thickness of the phloem vessels in plants subjected to a water deficit (25\% of field capacity). These and other anatomical changes were observed by Queiroz-Voltan et al. (2014) in coffee plants that were tolerant to water deficit. Thus, the use of the water retaining polymer positively influenced the anatomical characteristics evaluated in this study, mainly at the lower levels of irrigation, thereby demonstrating the effectiveness of the polymer in providing water to the plants under soil water-limiting conditions.

The gas exchange of plants can be reduced due to the imposed water deficit (Pasqualotto et al., 2020). The reduction of stomatal conductance can limit the supply of $\mathrm{CO}_{2}$ to the carboxylation sites (DaMatta; Ramalho, 2006) and, as consequence, reduce the accumulation of biomass and productivity. In the present work, up to $65 \%-70 \%$ of field capacity, increasing water availability for coffee plants improved $\mathrm{CO}_{2}$ absorption, likely due to an increasing amount of internal carbon, which in turn would enhance energy production required for coffee growth.

The lowest value for leaf water potential (i.e., most negative value) observed in this study was $-0.52 \mathrm{MPa}$ at $25 \%$ of field capacity, which was above the value found to be the leaf water potential threshold for arabica coffee plants by Kumar and Tieszen (1980), beyond which, photosynthesis becomes limited by water-deficit (-1.0 MPa).

The physiological variables were evaluated one day after water replenishment; therefore, despite the observed values of water potential, at the time of the evaluation the plants may have recovered momentarily. However, despite the high values of water potential observed, the trend followed by leaf water potential in response to the treatments was evident and consistent with other variables analyzed, thus demonstrating the effectiveness of the water-retaining polymer.

Finally, in addition to its direct and indirect effects on photosynthesis, water stress often affects plant growth negatively (Praxedes et al., 2006), as confirmed by the results summarized herein, which showed that, in order to minimize the effects of drought, coffee plants used various morphological and physiological mechanisms of adaptation to retard dehydration (Worku; Astatkie, 2010). This combination of mechanisms was also observed in coffee genotypes with greater drought tolerance (Silva et al., 2013).

\section{CONCLUSION}

The use of water-retaining polymer in the deployment of coffee fields provides greater hydration to the plants over time, optimizing the rain or irrigation water, guaranteeing the anatomical and physiological functionality, and consequently the growth of the plants. 


\section{ACKNOWLEDGMENTS}

The authors gratefully acknowledge support to this study by the CAPES (Coordination for the Improvement of Higher Education Personnel), the CNPq (National Council for Scientific and Technological Development), and the FAPEMIG (Minas Gerais State Research Support Foundation). They also express their gratitude to the InovaCafé (Coffee Innovation Agency), the Consórcio Pesquisa Café, and the INCT-Café (National Coffee Science and Technology Institute) for the development of studies, researches, and innovations that promote entrepreneurship in the coffee agro-industrial sector.

\section{AUTHORS' CONTRIBUTIONS}

TBR performed the experiment and wrote the manuscript, VHSS co-worked the manuscript and met the journal's standards, RJG supervised the experiment and coworked the manuscript, DTC co-worked the manuscript and work on the statistical analyses, MAFC co-worked the manuscript. All authors reviewed and approved the final version of the work.

\section{REFERENCES}

ASSIS, G. A. et al. Correlação entre crescimento e produtividade do cafeeiro em função do regime hídrico e densidade de plantio. Bioscience Journal, 30(3):666-676, 2014.

AZEVEDO, T. L. F. et al. Níveis de polímero superabsorvente, frequências de irrigação e crescimento de mudas de café. Acta Scientiarum, 24(5):1239-1243, 2002 .

\section{BANZATTO, D. A.; KRONKA, S. N. Experimentação} agrícola. 3. ed. Jaboticabal: Funep, 1995. 237p.

BATISTA, L. A. et al. Anatomia foliar e potencial hídrico na tolerância de cultivares de café ao estresse hídrico. Ciência Agronômica, 41(3):475-481, 2010.

BERNARDO, S. Manual de irrigação. 4. ed. Viçosa, MG: UFV, 1987. 488p.

CAMARGO, M. A. B.; MARENCO, R. A. Density, size and distribution of stomata in 35 rainforest tree species in Central Amazonia. Acta Amazonica, 41(2):205-212, 2011.

CARVALHO, C. H. M. et al. Evolução do crescimento do cafeeiro (Coffea arabica L.) irrigado e não irrigado em duas densidades de plantio. Ciência e Agrotecnologia, 30(2):243-250, 2006.
CASTANHEIRA, D. T. et al. Agronomic techniques for mitigating the effects of water restriction on coffee crops. Coffee Science, 14(1):104-115, 2019.

CASTRO, E. M. et al. Aspectos anatômicos e fisiológicos de plantas de guaco submetidas a diferentes fotoperíodos. Horticultura Brasileira, 23(3):846-850, 2005.

DAMATTA, F. M.; RAMALHO, J. C. Impacts of drought and temperature stress on coffee physiology and production: A review. Brazilian Journal of Plant Physiology, 18(1):55-81, 2006.

FARIA, R. T. D.; SIQUEIRA, R. Produtividade do cafeeiro e cultivos intercalares sob diferentes regimes hídricos. Bragantia, 64(4):583-590, 2005.

FERREIRA, D. F. Sisvar: A computer statistical analysis system. Ciência e Agrotecnologia, 35(6):1039-1042, 2011.

GOMIDE, M. B. et al. Comparação entre métodos de determinação de área foliar em cafeeiros 'Mundo Novo' e 'Catuaí'. Ciência e Prática, 1(2):118-23, 1977.

GRISI, F. A. et al. Avaliações anatômicas foliares em mudas de café 'Catuaí' e 'Siriema' submetidas ao estresse hídrico. Ciência e Agrotecnologia, 32(6):1730-1736, 2008.

GUIMARÃES, P. T. G. et al. Cafeeiro. In: RIBEIRO A. C. et al. Recomendações para o uso de corretivos e fertilizantes em Minas Gerais - 5a aproximação. Viçosa, MG: CFSEMG, p. 289-302, 1999.

GUIMARÃES, R. J. et al. Coffee growing and post-harvest processing. In: FARAH, A. (Org.). Coffee: Production, quality and chemistry. 1ed. Londres - United Kingdom: Royal Society of Chemistry, p. 26-88, 2019.

HARRISON, E. L. et al. The influence of stomatal morphology and distribution on photosynthetic gas exchange. The Plant Journal, 101(4):768-77, 2020.

HÖLTTÄ, T. et al. Linking phloem function to structure: analysis with a coupled xylem-phloem transport model. Journal of Theoretical Biology, 259(2):325-37, 2009.

JORGE, L. A. C.; SILVA, D. J. C. B. Safira: Manual de utilização. São Carlos: EMBRAPA, 2010. 29p.

KRAUS, J. E.; ARDUIN, M. Manual básico de métodos em morfologia vegetal. Seropedica, RJ: Universidade Rural, 1997. 198p.

KUFA, T.; BURKHARDT, J. Stomatal Characteristics in Arabica Coffee Germplasm Accessions under Contrasting Environments at Jimma, Southwestern Ethiopia. International Journal of Botany, 7(1):63-72, 2011. 
KUMAR, D.; TIESZEN, L. L. Photosynthesis in Coffea arabica. I. Effects of light and temperature. Experimental Agriculture, 16(1):13-19, 1980.

LAMONT, G. P.; O’CONNELL, M. A. Shelf-life of bedding plants as influenced by potting media and hydropolímero hidrorretentors. Scientia Horticulturae, 31(1-2):141-149, 1987.

LIU, T. Y.; CHANG, C. Y.; CHIOU, T. J. The long-distance signaling of mineral macronutrients. Curr. Opin. Current Opinion in Plant Biology, 12(3):312-319, 2013.

MARQUES, P. A. A.; MELO CRIPA, M. A. de.; MARTINEZ, E. H. Hidropolímero hidrorretentor como substituto da irrigação complementar em viveiro telado de mudas de cafeeiro. Ciência Rural, 43(1):1-7, 2013.

MELO, H.C. et al. Influência da aplicação de cálcio e alagamento do solo sobre características anatômicas das folhas de milho (Zea mays L.) "Saracura" BRS-4154. Revista Brasileira de Milho e Sorgo, 3(3):333-342, 2004.

MORANDI, M. A. B.; BETTIOL, W.; REZENDE, L. C. Insumos biológicos para o manejo de pragas e doenças na cultura do morango. Informe Agropecuário, 35:64-74, 2014.

NAGY-DÉRI, H. et al. Changes in chloroplast morphology of different parenchyma cells in leaves of Haberlea rhodopensis Friv. during desiccation and following rehydration. Photosynthetica, 49:119-126, 2011.

OLIVEIRA, N. K. et al. Anatomia foliar de cafeeiros implantados com o uso de polímero hidrorretentor. Coffee Science, 9(2):258-265, 2014.

PASQUALOTTO, A. T. et al. Root morphology, gas exchange and chlorophyll fluorescence of coffee cultivars and progenies are altered by Meloidogyne paranaensis infestation and water deficit. Journal of Phytopathology. 168(4):220-227, 2020.

PIEVE, L. M. et al. Uso de polímero hidrorretentor na implantação de lavouras cafeeiras. Coffee Science, 8(3):314-323, 2013.
PRAXEDES, S. C. et al. Effects of long-term soil drought on photosynthesis and carbohydrate metabolism in mature robusta coffee (Coffea canephora Pierre var. kouillou) leaves. Environmental and Experimental Botany, 56(3):263-273, 2006.

PREVEDELLO, C. L.; BALENA, S. P. Efeitos de polímeros hidrorretentores as propriedades físico-hídricas de dois meios porosos. Revista Brasileira de Ciência do Solo, 24(2):251-258, 2000.

QUEIROZ-VOLTAN, R. B. et al. Caracterização da anatomia foliar de cafeeiros arábica em diferentes períodos sazonais. Biotemas, 27(4):1-10, 2014.

SEVANTO, S. Review paper phloem transport and drought. Journal of Experimental Botany, 65(7):1751-1759, 2014.

SILVA, P. E. M. et al. The functional divergence of biomass partitioning, carbon gain and water use in Coffea canephora in response to the water supply: Implications for breeding aimed at improving drought tolerance. Environmental and Experimental Botany, 87:49-57, 2013.

SOUZA, A. J. J. et al. Quantitative analysis of growth in coffee plants cultivated with a water-retaining polymer in an irrigated system. Revista Ciência Agronômica, 47(1):162-171, 2016.

SOUZA, T. C. et al. Leaf plasticity in successive selection cycles of 'Saracura' maize in response to periodic soil flooding. Pesquisa Agropecuária Brasileira, 45(1):1624,2010 .

VALLONE, H. S. et al. Substituição do substrato comercial por casca de arroz carbonizada para produção de mudas de cafeeiro em tubetes na presença de polímero hidrorretentor. Ciência e Agrotecnologia, 28(3):593-599, 2004.

WORKU, M.; ASTATKIE, T. Dry matter partitioning and physiological responses of Coffea arabica varieties to soil moisture deficit stress at the seedling stage in Southwest Ethiopia. African Journal of Agricultural Research, 5(15):2066-2072, 2010 